\title{
PENGELOLAAN LIMBAH MEDIS PADAT B3 DI PUSKESMAS PERAWATAN BETUNGAN KOTA BENGKULU TAHUN 2021
}

\section{B3 SOLID MEDICAL WASTE MANAGEMENT AT THE BETUNGAN CARE HEALTH CENTER, BENGKULU IN 2021}

\author{
Oleh: \\ Hestika Nurhayati ${ }^{1}$, Agus Ramon ${ }^{2}$, Henni Febriawati ${ }^{3}$, Nopia Wati ${ }^{4}$ \\ 1,2,3.4Prodi Kesehatan Masyarakat Fakultas IImu Kesehatan Universitas Muhammadiyah Bengkulu
}

\begin{abstract}
The Betungan Health Center in Bengkulu City has an outpatient and nursing service unit. The health services provided by the Puskesmas in Betungan in Bengkulu City can have a negative impact on the environment and the surrounding community. The general objective of this research is to know the implementation of the B3 solid medical waste management system at the Betungan Health Center, Bengkulu City. This type of research is a qualitative research with a descriptive approach. The research location was carried out at the Betungan Health Center, Bengkulu City in January-February 2021. Sources of informants were health care and cleaning service officers. Data collection techniques by means of interviews, observation and documentation. The results showed that the identification of B3 waste, Temporary Shelters (TPS) for solid B3 medical and further processing of B3 Solid Medical Waste at the Betungan Health Center were in accordance with Minister of Health Regulation No. 7 of 2019. Meanwhile, the sorting of B3 solid medical waste, the storage and transportation of B3 solid medical waste is not in accordance with Minister of Health Regulation No. 7 Years 2019 The conclusion from the results of the study that solid medical waste treatment at the Betungan Health Center in Bengkulu City was not in accordance with the Minister of Health Regulation No. 7 of 2019, because there are still some that do not meet the standards at the stages of selection, storage and transportation.
\end{abstract}

Keywords: Processing, Medical Waste, Health Center

\begin{abstract}
ABSTRAK
Puskesmas Perawatan Betungan Kota Bengkulu memiliki unit pelayanan rawat jalan dan Perawatan. Pelayanan kesehatan yang dilakukan oleh Puskesmas di Betungan di Kota Bengkulu tersebut dapat memberikan dampak negative terhadap lingkungan dan masyarakat sekitar. Tujuan umum dari penelitian ini adalah mengetahuai pelaksanaan sistem pengelolaan limbah medis padat B3 di Puskesmas Perawatan Betungan Kota Bengkulu. Jenis penelitian ini adalah Penelitian kualitatif dengan pendekatan deskriptif. Lokasi penelitian dilakukan di puskesmas Perawatan Betungan Kota Bengkulu pada bulan Januari-Februari 2021. Sumber informan adalah petugas kesling dan cleaning service. Teknik pengumpulan data dengan cara wawancara, observasi dan dokumentasi. Hasil didapatkan bahwa identifikasi limbah B3, Tempat Penampungan Sementara (TPS) medis padat B3 dan Pengolahan lanjutan Limbah Medis Padat B3 di Puskesmas Perawatan Betungan sudah sesuai Permenkes No. 7 Taun 2019. Sedangkan pemilahan limbah medis padat B3, pewadahan dan pengangkutan limbah medis padat B3 belum sesuai Permenkes No. 7 Taun 2019 Kesimpulan dari hasil penelitian bahwa pengolahan limbah medis padat di Puskesmas Perawatan Betungan Kota Bengkulu belum sesuai dengan Permenkes No. 7 Taun 2019, karena masih ada yang tidak sesuai standar pada tahapan pemilihan, pewadahan dan pengangkutan.
\end{abstract}

Kata Kunci: Pengolahan, Limbah Medis, Puskesmas

\section{PENDAHULUAN}

Pelayanan kesehatan masyarakat adalah pelayanan yang bersifat publik (public goods) dengan tujuan utama memelihara dan meningkatkan kesehatan serta mencegah penyakit tanpa mengabaikan penyembuhan 
penyakit dan pemulihan kesehatan. Pemberantasan penyakit, penyehatan lingkungan, perbaikan gizi, peningkatan kesehatan keluarga, keluarga berencana, kesehatan jiwa serta berbagai program kesehatan masyarakat lainnya. Layanan kesehatan masyarakat tersebut antara lain promosi kesehatan, sedangkan Pelayanan kesehatan perorangan adalah pelayanan yang bersifat pribadi (private goods) dengan tujuan utama menyembuhkan penyakit dan pemulihan kesehatan perorangan, tanpa mengabaikan pemeliharaan kesehatan dan pencegahan penyakit (Depkes RI, 2009).

Standar baku mutu kesehatan lingkungan dan persyaratan kesehatan rumah sakit telah mengalami perubahan seiring dengan perkembangan kebijakan,peraturan perundangundangan, dan pedoman teknis terkait kesehatan lingkungan. Ketentuan persyaratan kesehatan lingkungan rumah sakit yang tertuang dalam Keputusan Menteri KesehatanNomor1204/MENKES/SK/X/2004 tentang Persyaratan Kesehatan Lingkungan Rumah Sakit telah dilakukan pembaharuan/adaptasi standar menjadi Peraturan Menteri Kesehatan Nomor 7 Tahun 2019 tentang Kesehatan Lingkungan Rumah Sakit. (Permenkes RI 2019). Puskesmas merupakan unit pelaksana teknis dari dinas kesehatan kabupaten/ kota yang berada di wilayah kecamatan untuk melaksanakan tugastugas operasional pembangunan kesehatan. Pembangunan Puskesmas di tiap kecamatan memiliki peran yang sangat penting dalam memelihara kesehatan masyarakat.

Bertambahnya jumlah pengunjung pada fasilitas kesehatan berdampak pada bertambahnya jumlah sampah medis yang dihasilkan. Sampah medis yang dihasilkan dari fasilitas kesehatan mempunyai risiko terhadap lingkungan dan kesehatan masyarakat terutama terhadap petugas pengelola sampah, tenaga kesehatan pasien dan keluarganya. Tujuan pengelolaan limbah ialah melindungi petugas pembuangan limbah dari perlukaan, melindungi penyebaran infeksi terhadap para petugas kesehatan, mencegah penularan infeksi pada masyarakat sekitarnya, membuang bahanbahan berbahaya (bahan toksik dan radioaktif) dengan aman. Tumpukan limbah terbuka harus dihindari, karena menjadi objek pemulung yang akan memanfaatkan limbah yang terkontaminasi, dapat menyebabkan perlukaan, menimbulkan bau busuk dan mengundang lalat dan hewan penyebar penyakit lainnya. Berdasarkan hasil penelitian Pratiwi tahun 2016, terdapat 64,6\% puskesmas yang telah melaksanakan pemilahan limbah medis dan non medis. Akan tetapi, hanya $26,8 \%$ puskesmas yang memiliki izin insenerator sedangkan $73,2 \%$ tidak memiliki izin fasilitas tersebut yang menunjukkan bahwa pengelolaan limbah medis padat yang masih buruk.

Provinsi Bengkulu terdapat 180 Puskesmas dan 20 Puskesmas di Kota Bengkulu dengan rincian 3 Puskesmas Perawatan dan 17 Puskesmas Non Perawatan. (Dinkes Kota Bengkulu, 2020). Puskesmas Perawatan Betungan merupakan salah satu puskesmas Perawatan yang menjadi pusat pelayanan kesehatan di Kota Bengkulu, Kegiatan pelayanan kesehatan yang diselenggarakan oleh Puskesmas mendorong masyarakat untuk bersikap mandiri dalam menjaga kesehatan, baik secara langsung melalui upaya pemulihan dan pemeliharaan kesehatan maupun melalui upaya peningkatan kesadaran yang lebih tinggi pada upaya promotif dan preventif. Jenis pelayanan medis memberikan kesempatan kepada masyarakat untuk memulihkan dan memelihara kesehatannya, terutama fasilitas perawatan.

Puskesmas Perawatan Betungan Kota Bengkulu memiliki unit pelayanan rawat jalan dan Perawatan. Pelayanan kesehatan yang dilakukan oleh Puskesmas di Betungan di Kota Bengkulu tersebut dapat memberikan dampak positif dan dampak negatif. Dampak positif adalah meningkatkan derajat kesehatan masyarakat serta meningkatkan pengetahuan masyarakat di bidang kesehatan. Sedangkan dampak negatif yang diakibatkan dari pelayanan kesehatan adalah limbah padat B3 yang dapat menyebabkan penyakit dan pencemaran.

Berdasarkan hasil observasi dan wawancara prapenelitian yang telah dilakukan peneliti diketahui bahwa Puskesmas Perawatan 
Betungan Kota Bengkulu pengelolaan limbah medis padat B3 belum sesuai dengan Permenkes No.7 Tahun 2019, dimana terjadi penumpukkan limbah medis padat, belum dilakukan pemilahan sesuai dengan jenisnya. Sarana dan prasarana yang belum memadai seperti tempat sampah yang tidak dilapisi kantong plastik berwarna sesuai jenisnya, tempat sampahnya masih belum menggunakan kantong plastik tetapi langsung dimasukkan dan ditumpuk dalam kandus. Selain itu, pengangkutan limbah hanya dilakukan oleh cleaning service yang hanya berjumlah satu orang, sehingga tidak efektif dalam menjalankan tugasnya.

Dampak dari pengelolaan limbah yang kurang baik sangat merugikan kesehatan masyarakat dan dapat menurunkan derajat kesehatan masyarakat serta menimbulkan masalah kesehatan seperti tinginya angka kepadatan vektor penyakit (lalat, tikus, nyamuk, kecoa, dan lain-lain), pencemara udara, tanah, dan air, dan rendahnya nilai estetika. Hal ini juga dapat menyebabkan penyakit menular, seperti diare, penyakit kulit, demam berdarah dengue (DBD), kecacingan, dan lain-lain.

Berdasarkan hal diatas penulis ingin meneliti dengan judul "Analisis Pengelolaan Limbah Medis Padat B3 di Puskesmas Perawatan Betungan Kota Bengkulu"

\section{METODE PENELITIAN}

Jenis penelitian ini adalah Penelitian kualitatif dengan pendekatan deskriptif yaitu metode yang bertujuan memberikan Analisis Sistem Pengolahan Limbah Medis Padat B3 di Puskesmas Perawatan Betungan Kota Bengkulu. Lokasi penelitian dilakukan di puskesmas Perawatan Betungan Kota Bengkulu. dilaksanakan pada bulan Januari - Februari 2021. Informan petugas kesehatan lingkungan Puskesmas dan Cleaning Service Puskesmas. Teknik pengambilan data yang digunakan pada penelitian ini adalah berupa observasi dan wawancara dengan menggunakan pedoman wawancara.

Identifikasi Jenis Limbah Medis Padat B3
Identifikasi Jenis Limbah Medis Padat B3 di Puskesmas Perawatan Betungan Kota Bengkulu sudah sesuai dengan Peraturan Menteri Kesehatan Nomor 7 Tahun 2019 tentang Kesehatan Lingkungan Puskesmas, hal ini terlihat sudah di kelompokkan sesuai dengan jenis dan karakteristik limbah dengan melakukan wawancara dengan Informan 1 dan 2, dan Observasi yang lakukan, dimana berdasarkan temuan lapangan menunjukan petugas sudah mengelompokan jenis limbah sesuai jenis limbah seperti limbah medis yaitu: limbah tajam di masukan ke tempat khusus safety box dan limbah medis infeksius di masukan ke kantong pelastik warna kuning.

Informan Identifikasi sesuai jenis dan 1: $\quad$ karakteristik yang seperti limbah tajam dilakukan pewadahan khusus seperti sefty box kemudian limbah bekas pelayanan medis seperti kapas, has, ataupun henskun dari aktifitas mesdis itu ada tempat pewadahannya tempat sampah kedap air, tidak bocor, anti karat.

Cara mengidentifikasinya itu untuk limbah benda tajam itu ada logo atau tulisan limbah benda tajam, ada limbah medis, ada limbah umum/ limbah non medis, masing-masing tempat penampungan ada tempat penampungan yang digunakan kantong plastik, kalau untuk limbah medis kantong warna kuning dan kalau non medis katong plastik warna hitam, dan untuk limbah benda tajam menggunakan safety box itu cara mengidentifikasinya.

Mengidentifikasinya dengan membedakan tempat sampah medis berwarna kuning, benda tajam menggunakan safety box dan limba non medis berkantong warna hitam.

Informan Beda sampah, beda juga tempat 
2: sampahnyo. Sampah medis ditaro ditempat sampah medis, yang non medis ditaro di tempat sampah non medis.

\section{Pemilahan Limbah Medis Padat B3}

Pemilahan Limbah Medis Padat B3 di UPTD Puskesmas Perawatan Betungan Kota Bengkulu Bengkulu tidak sesuai dengan Peraturan Menteri Kesehatan Nomor 7 Tahun 2019 tentang Kesehatan Lingkungan Puskesmas, karena di dalam proses pemilhan masih ditemukan limbah medis dalam tempat sampah non medis saat pemilahan limbah dengan melakukan wawancara Informan 1 dan Informan 2 dengan melakukan Observasi lapangan dimana berdasarkan temuan lapangan menunjukan pemilihan masih ditemukan limbah medis dalam tempat sampah non medis saat pemilahan limbah seperti bekas obat, bekas botol bius, sarung tangan dan kasah bekas luka yang di lakukan oleh petugas yang bertugas.

Informan sesuai jenis dan karakteristik 1: yang seperti limbah tajam dilakukan pewadahan khusus kemudian limbah bekas pelayanan medis seperti kapas, has, ataupun henskun dari aktifitas mesdis itu ada tempat pewadahannya tempat sampah kedap air, tidak bocor, anti karat, dan limbah medis Merah, untuk limbah radioaktif Kuning, untuk limbah infeksius dan limbah patologis Ungu, untuk limbah sitotoksik Cokelat, untuk limbah bahan kimia kedaluwarsa, tumpahan, atau sisa kemasan, dan limbah farmasi.ada setiker logo, label untuk mengidentifikasi jenis karateristiknya.

Pemilhan dilakukan oleh petugas pengangkut limbah atau petugas pemilah Puskesmas Pearawatan Betungan ini bekerja sama dengan pihak ketiga dalam hal penangan limbah dengan PT. Artama Sentosa untuk pelaksana, pihak ketiga pengelolaan limbah medis Puskesmas. Petugas yang menggangkut dan petugas penggangkut dilengkapi dengan alat pelindung diri yaitu alat pelindung diri APD kemudian dari situ sampah di pilah berdasarkan jenis dan karakteristik limbah kalo limbah medis di bawah ke tempat penampungan sementara TPS medis kalu limbah non medis di bawah ketempat penampungan sementara TPS non medis menggukan trolly sampah yang kuat, kedap air anti karat.

Pemilahan dilakukan oleh petugas yang sedang bertugas di ruangan penghasil limbah dengan memasukan limbah sesuai jenis dan karakteristik limbah dan di bantui dengan pihak cleaning service untuk membantu pemilahan yang masih salah saat pemilhan limbah.

Informan Sudah di lakukan pemilihan yang 2: dilakukan dengan memisakan limbah medis di kantong warna kuning, jarum sintik ke safety box dan limbah non medis di kantong warna hitam, tetapi masih ada petugas yang salah meletakan limbah medis ketempat sampah non medis.

\section{Pewadahan/ Pengangkutan Limbah Medis Padat B3}

Pewadahan/ Pengangkutan Limbah Medis Padat B3 kegiatan pewadahan sudah terbuat dari bahan yang kuat, anti karat, muda di bersikan dan di bungkus pelastik sesuai jenisnya. Pengangkutan limbah padat di UPTD Puskesmas Perawatan Betungan Kota Bengkulu tidak sesuai dengan Peraturan Menteri Kesehatan Nomor 7 
Tahun 2019 tentang Kesehatan Lingkungan Puskesmas , karena dalam proses pengangkutan dari sumber pengangkutan limbah ke TPS, petugas yang mengangkut tidak menggunakan APD lengkap. Dengan melakukan wawancara dengan Informan 1 dan Informan 2 dengan melakukan Observasi lapangan menemukan ada petugas yang tidak menggunakan APD lengkap saat pengengangkutan limbah.

Informan Setiap ruangan pengahasil 1: limbah disediakan tempat atau wadah penampung limbah berupa tempat sampah yang kedap air dan anti karat, muda di bersikan memiliki penutup.

Setiap ruangan pengahasil limbah di sediakan tempat sampah untuk menampung limbah dan untuk limbah tajam menggunakan safety box

Setiap ruangan di sediakan tempat wadah penampung limbah berupa tempat sampah.

Informan Sudah ada wadah berupa 2: $\quad$ tempat sampah yang memiliki penutup

Informan Ada petugas khusus, untuk 1: petugas kebersihan termasuk pengangkutan sampah ini Puskesmas Pearawatan Betungan ini juga bekerja sama dengan pihak ketiga juga namanya PT. Artama Sentosa dari ruangan petugas kebersihan juga dari pihak ketiga PT. Artama Sentosa itu dari pengangkutan limbah medis kalau untuk ruangan internal petugas kebersihan, yang kerjasama dengan Artama dengan Nikosa itu tadi itu kerjasama dalam hal pengangkutan dan pengelolaan limbah medis Puskesmas yang bukti manifest, petugas kebersihan lingkungan puskesmas ini sekaligus cleaning servis mengngangkut sampah medis menggunakan $A P D$ masker, sarung tangan, dan mematuhi protocol kesehatan.

lya menggunkan APD lengkap

Masih ada petugas yang tidak menggunakan APD lengkap,seperti tidak menggunakan sarung tangan yang lengkap tidak menggukan alat angkut trolly pada saat pengangkutan limbah medis.

\section{Tempat Penampungan Sementara (TPS)}

Tempat Penampungan Sementara (TPS) di UPTD Puskesmas Perawatan Betungan Kota Bengkulu sudah sesuai dengan Peraturan Menteri Kesehatan Nomor 7 Tahun 2019 tentang Kesehatan Lingkungan Puskesmas, dengan melakukan wawancara dengan Informan 1 dengan melakukan Observasi lapangan, terlihat dari bangunan yang tertutup dari sinar matahari, memiliki tempat penampungan limbah sudah memiliki sekat pembatas dari tempat penampungan dan tempat penampungan tidak langsung bersentuhan dengan lantai, dan dilengkapi deangan fasilitas keselamatan.

$$
\text { Informan } 1 \text { Standar bagus TPS di }
$$
Puskesmas.

Artinya : TPS sudah sesuai dengan standar.

Kondisinya baik. Bangunan nyo lah tepisah.

Artinya : Kondisi TPS sudah baik, sesuai standar. Bangunan terpisah dengan bangunan lainnya.

lya sudah bagus TPS di Puskesmas.

.Informan lya disana sudah ada wadah 1: $\quad$ khusus. lya sudah ada wadah khusus. Sudah ada wadah khusu.

Informan 1 lya ada disana ada sekat- sekat yang medis, beracun, berbahaya 
terhadap lingkungan tidak langsung bertemu dengan lantai menggunkan palet.

"Iya sudah ada tempat limbah sesuai jenis dan karakteristik.

"Iya sudah di pisakan jenis dan karakteristiknya.

\section{Pengolahan lanjutan Limbah Medis Padat B3}

Pengolahan lanjutan Limbah Medis

Padat B3 di UPTD Puskesmas Perawatan Betungan Kota Bengkulu sudah sesuai dengan Peraturan Menteri Kesehatan Nomor 7 Tahun 2019 tentang Kesehatan Lingkungan, Puskesmas Pearawatan Betungan Kota Bengkulu tidak memiliki izin pengelolaan limbah dengan menggunkan insenerator, maka dari itu Puskesmas Perawatan Betungan, bekerja sama dengan pihak ketiga yaitu PT Artama Sentosa, dalam proses pengelolaan limbah medis yang di lakukan berdasarkan hasil wawancara dengan Informan 1 dan observasi lapangan menanyakan ke pihak kesling pada saat melakukan observasi kenapa tidak menggunkan insenerator karena pipa pembakaran kurang tinggi mengakibatkan polusi di sekitar Puskesmas Perawatan Betungan Kota Bengkulu yang tidak standar dengan spesifikasi insenerator Puskesmas Perawatab Betungan Kota Bengkulu belum standar sesuai Kementerian Lingkungan Hidup Republik Indonesia.

Informan Jadi gini di dalam kontrak 1: puskesmas ini menggunakan armada khusus mobil khusus, biasanya ada pemberitahuan dari Puskesmas jiwa biasanya limbah di TPS medis segera harus di angkut pihak puskesmas unit kesling menghubungi PT. pihak ketiganya kemudian dengan menggunakan armada khusus yang tertutp datanag menuju TPS medis dilakukan pengagkutan sebelum pengangkutan itu di lakukan penimbangan volume limbah yang akan di angkut, kemudian sesuai dengan kontrak juga keluar dari gerbang Puskesmas jiwa tidak lagi tanggung jawab dari puskesmas jadi sepenunya tanggung jawab pihak ketiga PT. Artama Sentosa. Mobil nya masuk sampai depan TPS, yang mengangkut, petugas menimbang juga dari meraka pihak ketiga.

biasanya ada pemberitahuan dari Puskesmas Perawatan Betungan biasanya limbah di TPS medis segara harus di angkut pihak puskesmas unit kesling menghubungi pihak ketiganya kemudian dengan menggunakan armada khusus yang tertutup datang menuju TPS medis dilakukan pengangkutan sebelum pengangkutan itu di lakukan penimbangan volume limbah yang akan di angkut,

pihak ketiga menggunakan armada khusus yang tertutp datang menuju TPS medis dilakukan pengagkutan sebelum pengangkutan itu dilakukan penimbangan volume limbah yang akan di angkut, kemudian sesuai dengan kontrak juga keluar dari gerbang Puskesmas tidak lagi tanggung jawab dari Puskesmas.

\section{PEMBAHASAN}

\section{Pengelolaan Limbah Medis Padat}

UPTD Puskesmas Perawatan Betungan Kota Bengkulu dalam hal pengelolaan limbah medis menggunakan pihak ke pihak ke ketiga yaitu PT. Artama Sentosa, dimana untuk pengelolaaan limbah medis dirumah sakit sendiri mulai dari minimalisasi, identifikasi, pemilahan, pewadahan dan penangkutan hingga tempat penampungan sementara (TPS) dan pegangkutan limbah dari TPS oleh pihak ketiga. 
Berdasarkan hasil penelitian dan hasil observasi yang peneliti lakukan di Puskesmas Perawatan Betungan Kota Bengkulu tentang Evaluasi Pengelolaan Limbah Medis Padat dijabarkan sebagai berikut :

Menurut Permenkes RI nomor 7 Tahun 2019 minimslisasi limbah medis padat, harus memenuhi ketentuan teknis sebagai berikut : Upaya pengurangan dan pemilahan limbah padat harus dilengkapi dengan SOP dan dapat dilakukan pemutakhiran secara berkala dan berkesinambungan.

Pengurangan limbah padat di rumah sakit, dilakukan dengan cara antara lain: Menghindari penggunaan material yang mengandung Bahan Berbahaya dan Beracun ap abila terdapat pilihan yang lain; Melakukan tata kelola yang baik terhadap setiap bahan atau material yang berpotensi menimbulkan gangguan kesehatan dan/atau pencemaran terhadap lingkungan; Melakukan tata kelola yang baik dalam pengadaan bahan kimia dan bahan farmasi untuk menghindari terjadinya penumpukan dan kedaluwarsa; Melakukan pencegahan dan perawatan berkala terhadap peralatan sesuai jadwal.

Berdasarkan hasil penelitian di ketahui kegiatan minimalisasi limbah medis di Puskesmas Perawatan Betungan Kota Bengkulu sesuai dengan Peraturan Menteri Kesehatan Nomor 7 Tahun 2019 tentang Kesehatan Lingkungan Rumah Sakit, hal tersebut terlihat dari beberapa kegiatan dalam usaha mengurangi produksi limbah medis padat di rumah sakit sudah dilakukan oleh Puskesmas Perawatan Betungan Kota Bengkulu Seperti : menyeleksi bahan- bahan semaksimal mungkin yang dapat menghasilkan limbah seperti mengganti tensimeter air raksa ke tensimeter digital, melakukan seleksi pembelian bahan-bahan sesuai dengan kebutuhan, menggunakan bahanbahan melalui sistem First In Frist Out (FIFO) dan Frist Expired Frist Out (FEFO) seperti yang dilakukan di bagian farmasi dengan menyimpan obat berdasarkan obat yang datang lebih dulu dan dikeluarkan lebih dulu serta obat yang memiliki tanggal kadaluarsa lebih cepat maka dikeluarkan lebih dulu dan menggunakan kembali (reuse) peralatan yang masih digunakan setelah melewati proses sterilisasi.

Hal tersebut juga di buktikan oleh hasil observasi yang peneliti lakukan, dimana berdasarkan temuan lapangan menunjukan bagian farmasi dengan menyimpan obat berdasarkan obat yang dikeluarkan lebih dulu serta obat yang memiliki tanggal kadaluarsa lebih cepat maka dikeluarkan lebih dulu untuk tidak bertumpuk obat yang kadaruarsa, dan menggunakan kembali (reuse) peralatan yang masih digunakan setelah melewati proses sterilisasi.

Hal ini sejalan dengan Peraturan Menteri Kesehatan Nomor 7 Tahun 2019 tentang Kesehatan Lingkungan Rumah Sakit menyebutkan bahwa minimalisasi merupakan salah satu upaya yang dilakukan oleh rumah sakit untuk mengurangi jumlah limbah yang ada dihasilkan dari kegiatan pelayanan minimalisasi limbah medis padat yang terdapat dalam Peraturan Menteri Kesehatan Nomor 7 Tahun 2019 tentang Kesehatan Lingkungan Rumah Sakit, terdiri dari: Setiap Rumah Sakit melakukan reduksi limbah di mulai dari sumber; Setiap Rumah Sakit harus mengelola dan mengawasi penggunaan bahan kimia yang berbahaya dan beracun; Setiap Rumah Sakit harus melakukan pengelolaan stok bahan kimia dan farmasi; Setiap peralatan yang digunakan dalam pengelolaan limbah medis mulai dari pengumpulan, pengangkutan dan pemusnahan harus melalui sertifikasi dari pihak yang berwenang.

Hal ini sesuai dengan penelitian Wulandari (2012) yang menyatakan bahwa minimalisasi dengan upaya reduksi/pemilahan dapat dilakukan untuk mengurangi Limbah Rumah Sakit yakni dengan menggunakan pendekatan pencegahan dan teknik yang meliputi perubahan bahan baku (pengelolaan dan modifikasi bahan), perubahan teknologi (modifikasi proses dan teknologi bersih), praktek operasi yang baik untuk limbah medis (housekeeping, segregasi limbah, preventive maintenance) dan perubahan produk yang tidak 
berbahaya untuk limbah medis (Wulandari, 2012).

\section{Identifikasi Jeni Limbah Medis Padat}

Menurut Permenkes RI nomor 7 Tahun 2019 Identifikasi jenis limbah medis padat harus memenuhi ketentuan teknis sebagai berikut: Identifikasi dilakukan oleh unit kerja kesehatan lingkungan dengan melibatkan unit penghasil limbah di Rumah Sakit; Limbah padat yang di identifkasi sesuai jenis limbah, karakteristik, sumber, volume yang dihasilkan, cara pewadahan, cara pengangkutan dan cara penyimpanan serta cara pengolahan; Hasil pelaksanaan identifikasi dilakukan pendokumentasian

Berdasarkan hasil penelitian di ketahui kegiatan identifikasi jenis limbah di Puskesmas Perawatan Betungan Kota Bengkulu sudah sesuai dengan Peraturan Menteri Kesehatan Nomor 7 Tahun 2019 tentang Kesehatan Lingkungan Rumah Sakit, hal ini terlihat sudah di kelompokkan sesuai dengan jenis dan karakteristiknya, yang terdiri dari limbah infeksius, patologi, limbah benda tajam, limbah farmasi, limbah sitotoksik, limbah kimiawi yang di lakukan oleh petugas yang sedang bertugas di dalam ruangan pelayaan medis seperti mengelompokan limbah medis seperti bekas sarung tangan, bekas pembersi kasa luka, bekas botol bius di masukan ke tempat sampah medis yang pelastik warna kuning dan limbah tajam memiliki tempat khusus yang di masukan ke safety box yang di lakukan oleh petugas yang betugas.

Hal tersebut juga di buktikan oleh hasil observasi yang peneliti lakukan, dimana berdasarkan temuan lapangan menunjukan petugas sudah mengelompokan jenis limbah sesuai jenis limbah seperti limbah medis yaitu: limbah tajam di masukan ke tempat khusus safety box dan limbah ifeksius di masukan ke kantong pelastik warna kuning. Untuk limbah tajam di pisakan dari limbah medis lainnya seperti bekas sarung tangan bekas pembersi kasa luka, bekas botol bius dan bekas bungkus obat di masukan ke tempat sampah medis yang di bungkus pelastik warna kuning dan limbah tajam di masukan ke safety box, limbah di masukan oleh petugas yang betugas di ruangan pelayaan di rumah sakit, dan limbah non medis di masukan ke tempat sampah non medis yang berbungkus pelastik warna hitam.

Hal ini sejalan dengan Peraturan Menteri Kesehatan Nomor 7 Tahun 2019 tentang Kesehatan Lingkungan Rumah Sakit, limbah medis padat harus di kelompokkan sesuai dengan jenis dan karakteristiknya, yang terdiri dari limbah infeksius, patologi, limbah benda tajam, limbah farmasi, limbah sitotoksik, limbah kimiawi, limbah radioaktif dan limbah logam berat. Jenis limbah yang dihasilkan tersebut dibedakan menjadi 5 berdasarkan kategori dan pewadahannya, yaitu limbah medis infeksius dengan tempat sampah dan kantong plastik warna kuning, limbah benda tajam dengan tempat sampah Safetybox, limbah medis sitotoksik dengan temapat sampah dan kantong plastik warna ungu, limbah medis radiologi dengan tempat sampah dan kantong plastik warna mera, limbah medis farmasi dengan tempat sampah dan kantong plastik warna coklat (Kemenkes, 2019).

Menurut Adisasmito (2011), kelancaran penanganan dan penampungan, pengurangan jumlah limbah yang memerlukan perlakuan khusus, dengan pemisahan limbah medis dan non medis, melakukan pengemasan dan pemberian label yang jelas dari berbagai jenis limbah medis dan non medis. Pengemasan dan pemberian label yang jelas dari berbagai jenis limbah untuk mengurangi biaya, tenaga kerja, dan pembuangan, pemisahan limbah berbahaya dari semua limbah pada tempat penghasil limbah akan mengurangi kemungkinan kesalahan petugas (Adisasmito, 2011).

\section{Pemilahan Limbah Medis Padat}

Menurut Permenkes RI nomor 7 Tahun 2019 pemilhan limbah medis harus memenuhi ketentuan teknis sebagai berikut : Memisahkan limbah padat berdasarkan jenis, kelompok, dan/atau karakteristik limbah medis; Mewadahi limbah padat sesuai kelompok limbah. wadah limbah dilengkapi dengan palet.

Berdasarkan hasil penelitian di ketahui kegiatan pemilahan limbah padat di Puskesmas 
Perawatan Betungan Kota Bengkulu Bengkulu tidak sesuai dengan Peraturan Menteri Kesehatan Nomor 7 Tahun 2019 tentang Kesehatan Lingkungan Rumah Sakit, karena di dalam proses pemilhan masih ditemukan limbah medis dalam tempat sampah non medis saat pemilahan limbah. Dalam pelaksanaannya di Puskesmas Perawatan Betungan Kota Bengkulu sudah melakukan pemilahan antara limbah medis, limbah non medis dan limbah medis benda tajam pada setiap sumber penghasil limbah medis sudah disediakan secara terpisah tetapi masih ditemukan sampah yang tidak sesuai dengan jenis dalam kategori pemilahannya oleh petugas yang berada di ruangan penghasil limbah.

Hal tersebut juga di buktikan oleh hasil observasi yang peneliti lakukan, dimana berdasarkan temuan lapangan menunjukan pemilhan masih ditemukan limbah medis dalam tempat sampah non medis saat pemilahan limbah seperti bekas obat, bekas botol bius, sarung tangan dan kasah bekas luka yang di lakukan oleh petugas yang bertugas, pada saat ditanyakan ke informan trianggulasi sudah sering terjadi salah penempatan limbah medis yang salah dimasukan ke tempat sampah non medis oleh petugas yang betugas di ruangan, untuk itu perlu dilakukan pengawasan SPO pengelolaan limbah dan melakukan evaluasi tahapan pengelolaan limbah medis di ruangan penghasil limbah agar tidak terjadi kembali kelalaian/ kesalahan dalam pembuangan sampah ke tempat sampah sesuai jenis dan kareteristik limbah oleh petugas yang betugas di ruangan penghasil limbah, dan di Puskesmas Perawatan Betungan sudah meletakan wadah/ tempat sampah yang di bungkus pelastik warna kuning untuk limbah medis dan kantong pelastik hitam untuk limbah non medis, di harapkan petugas sadar dan tidak mengulangi lagi kesalahan dalam pembuangan sampah medis di tempat sampah non medis.

Menurut Adisasmito, (2011) limbah dipilah- pilah dengan mempertimbangkan halhal yaitu kelancaran penanganan dan penampungan, pengurangan jumlah limbah yang memerlukan perlakuan khusus, dengan pemisahan limbah medis dan non medis, diusahakan sedikit mungkin menggunakan bahan kimia, pengemasan dan pemberian label yang jelas dari berbagai jenis limbah medis dan non medis, pengemasan dan pemberian label yang jelas dari berbagai jenis limbah untuk mengurangi biaya, tenaga kerja, dan pembuangan, pemisahan limbah berbahaya dari semua limbah pada tempat penghasil limbah akan mengurangi kemungkinan kesalahan petugas dan penanganan (Adisasmito, 2011).

Menurut Kusumah (2014), peletakan tempat sampah di setiap lorong harus lebih diperbanyak karena untuk meminimalisir adanya pengunjung yang kesusahan membuang limbah dan meminimalisir kesalahan membuang lihmba sembarangan dan adanya percampuran limbah medis dan non medis (Kusumah, 2014).

Setiap ruangan yang menghasilkan limbah medis disediakan tempat sampah dengan wadah dan kantong pelastik yang warnanya disesuaikan dengan jenis limbah peruntukannya. Hal ini juga sesuai dengan yang tercantum dalam Peraturan Menteri Kesehatan Nomor 7 Tahun 2019 tentang Kesehatan Lingkungan Rumah Sakit yang menyebutkan pemilhan harus dilakukan mulai dari sumber penghasil limbah (Kemenkes, 2019).

Dalam pelaksanaannya, puskesmas menyediakan dua kantong plastik untuk melapisi tempat sampah. Limbah medis menggunakan kantong plastik kuning dan limbah non-medis menggunakan kantong plastik hitam. Meskipun sudah disediakan wadah terpisah dengan warna kantong plastik yang berbeda. Akan tetapi, dalam pelaksanaannya masih ditemukan pembuangan limbah medis dan non medis tidak pada tempatnya. Hal ini serupa dengan Penelitian Wulandari, (2012) bahwa masih adanya percampuran limbah medis dan non medis. Hasil tersebut didukung WHO, hasil kajian tersebut menunjukkan bahwa $65 \%$ Rumah sakit telah melakukan pemilahan antara limbah medis dan limbah domestik (kantong plastik kuning dan hitam), tetapi masih sering terjadi salah tempat sehingga terjadi percampuran antara limbah 
medis dan non medis. Oleh karena itu, perlu adanya pemilahan sampah dari sumber yang harus dilakukan oleh petugas dan cleaning servis sebelum dipindahkan ke kontainer TPS rumah sakit. seperti yang dikemukaan oleh Wulandari (2012) bahwa untuk mengurangi percampuran limbah perlu adanya pemilahan sampah dari sumber mulai dari sampah yang dapat digunakan dan tidak dapat digunakan dan sampah yang kering dan basah (Wulandari, 2012).

Hasil penelitian ini selaras dengan penelitian wulandari (2012) yang mengatakan bahwa untuk pengangkutan limbah seharusnya menggunakan trolly yang tertutup untuk menghindari kecelakaan dan penyebaran kuman penyakit. Dapat diupayakan dengan pembuatan tutup sederhana dari bahan kedap air, mudah dibersihkan dan mudah dibuka dan ditutup seperti terbuat dari plastik atau kayu yang dilapisi bahan tahan terhadap air (wulandari, 2012).

\section{Pewadahan dan Pengangkutan Limbah Medis Padat B3}

Menurut Permenkes RI nomor 7 Tahun 2019, Alat angkut (trolly) limbah medis harus memenuhi ketentuan teknis sebagai berikut : Tahapan penanganan limbah padat harus dilengkapi dengan Standar Prosedur Operasional (SPO) dan dilakukan pemutakhiran secara berkala dan berkesinambungan; Standar Prosedur Operasional SPO penanganan limbah padat disosialisasikan kepada kepala dan staf unit kerja yang terkait dengan limbah padat di rumah sakit; Khusus untuk limbah medis tumpahan dilantai atau dipermukaan lain di ruangan seperti tumpahan darah dan cairan tubuh, tumpahan cairan bahan kimia berbahaya, tumpahan cairan mercury dari alat kesehatan dan tumpahan sitotoksik harus dibersihkan menggunakan perangkat alat pembersih (spill kit) atau dengan alat dan metode pembersihan lain yang memenuhi syarat. Hasil pembersihan limbah medis tersebut ditempatkan pada wadah khusus dan penanganan selanjutnya diperlakukan sebagai limbah padat, serta dilakukan pencatatan dan pelaporan kepada unit kerja terkait di rumah sakit; Perangkat alat pembersih (spill kit) atau alat metode pembersih lain untuk limbah padat harus selalu disiapkan di ruangan sumber dan dilengkapi cara penggunaan dan data keamanan bahan (MSDS); Pewadahan limbah padat diruangan sumber sebelum dibawa ke TPS Limbah medis harus ditempatkan pada tempat/wadah khusus yang kuat dan anti karat dan kedap air, terbuat dari bahan yang mudah dibersihkan, dilengkapi penutup, dilengkapi dengan simbol, dan diletakkan pada tempat yang jauh dari jangkauan orang umum. Limbah padat di ruangan sumber yang diserahkan atau diambil petugas limbah padat rumah sakit untuk dibahwa ke Tempat Penampungan Sementara TPS limbah padat, harus dilengkapi dengan berita acara penyerahan, yang minimal berisi hari dan tanggal penyerahan, asal limbah (lokasi sumber), jenis limbah padat, bentuk limbah padat, volume limbah padat dan cara pewadahan/pengemasan limbah padat. Pengangkutan limbah padat dari ruangan sumber ke Tempat Penampungan Sementara (TPS) limbah padat harus menggunakan kereta angkut khusus berbahan kedap air, mudah dibersihkan, dilengkapi penutup, tahan karat dan bocor. Pengangkutan limbah tersebut menggunakan jalur (jalan) khusus yang jauh dari kepadatan orang di ruangan Rumah Sakit. Pengangkutan limbah padat dari ruangan sumber ke Tempat Penamungan Sementara (TPS) dilakukan oleh petugas yang sudah mendapatkan pelatihan penanganan limbah padat dan petugas harus menggunakan pakaian dan alat pelindung diri yang memadai.

Berdasarkan hasil penelitian di ketahui kegiatan pewadahan sudah terbuat dari bahan yang kuat, anti karat, muda di bersikan dan di bungkus pelastik sesuai jenisnya. Pengangkutan limbah padat di Puskesmas Perawatan Betungan Kota Bengkulu tidak sesuai dengan Peraturan Menteri Kesehatan Nomor 7 Tahun 2019 tentang Kesehatan Lingkungan Rumah Sakit, karena dalam proses pengangkutan dari sumber pengangkutan limbah ke TPS, petugas yang mengangkut tidak menggunakan APD lengkap, dalam pelaksanaannya di Puskesmas Perawatan Betungan Kota Bengkulu proses pengnagkutan sudah mempasilitasi dengan APD lengkap 
seperti helem, sarung tangan, masker, sepatu boot, tetapi masih ada cleaning servis tidak menggunkan APD lengkap pada saat pengengkutan limbah medis.

Hal tersebut juga di buktikan oleh hasil observasi yang peneliti lakukan, dimana berdasarkan temuan lapangan, pewadahan sudah di bungkus dengan pelastik sesuai jenisnya dan terbuat dari bahan yang kuat, anti karat mudah di bersikan, pengangkutan menunjukan petugas yang mengangkut limbah medis tidak menggunakan APD lengkap pada saat pengangkutan limbah medis, petugas hanya menggunakan satu sarung tangan dan masker tidak di pakai dengan benar pada saat pengangkutan limbah medis, untuk itu perlu dilakukan pengawasan terhadap petugas pengngkut dan memberikan pelatihan agar saat petugas melakukan pengangkutan limbah, petugas menggunakan APD lengkap dan petugas sadar untuk menjaga keshatan dirinya sendiri pada saat bekerja, dan petugas harus menaati peraturan tentang SPO pengelolaan limbah dan Permenkes No 7 tahun 2019 tentang kesehatan rumah sakit, yang berlaku di Puskesmas Perawatan Betungan Kota Bengkulu.

$\mathrm{Hal}$ ini tidak sejalan dengan Peraturan Menteri Kesehatan Nomor 7 Tahun 2019 tentang Kesehatan Lingkungan Rumah Sakit, pengangkutan limbah medis padat harus mengnggunakan APD lengkap, yaitu helem, sarung tangan, masker, sepatu boot (Kemenkes, 2019).

Petugas dan cleaning servis yang mengangkut sampah medis dan non medis Rumah Sakit sudah difasilitasi dengan alat pelindung diri (APD) berupa topi, sepatu boot, sarung tangan khusus, masker oleh pihak Higiene Sanitasi (HS). Namun pada keadaan sesungguhnya di lapangan petugas dan cleaning servis ada yang belum menggunakan APD lengkap seperti topi, sepatu boot, dan sarung tangan khusus medis (berwarna merah dan kuning). Hal ini dikarenakan kesadaran petugas dan cleaning servis terkait APD yang masih kurang dan kurangnya disiplin pada petugas dan cleaning servis untuk menggunakan APD lengkap guna melindungi dari adanya kecelakan pada proses pengelolaan limbah padat rumah sakit. Oleh karena itu, perlu adanya penegasan dalam aturan untuk petugas dan cleaning servis, pengawasan yang lebih ketat selama proses pengelolaan limbah di Rumah Sakit, proses pengangkutan limbah medis merupakan kegiatan yang beresiko terhadap keselamatan dan kesehatan pekerja apabila tidak menggunakan APD dan tidak dibekali dengan pelatihan karena pelatihan pekerja, penggunaan APD sangat diperlukan bagi orang yang beresiko dalam menangani limbah medis terutama petugas dan cleaning servis (Riza, 2014).

Hasil penelitian ini juga selaras dengan penelitian Domy (2013) yang mengatakan bahwa hal yang perlu diperhatikan adalah karyawan menggunakan APD demi keselamatan dan menjaga agar tidak terkontaminasi dengan bibit penyakit yang ditularkan melalui sampah. Perlu pelatihan khusus dan pengawasan mengenai pengelolaan sampah yang baik dan benar khususnya bagi para petugas pengangkut sampah dan cleaning servis (Domy, 2013).

Tempat Penampungan Sementra (TPS)

Menurut Permenkes RI nomor 7 Tahun 2019 TPS limbah medis harus memenuhi ketentuan teknis sebagai berikut: Cara penyimpanan limbah padat harus dilengkapi dengan SPO dan dapat dilakukan pemutakhiran/revisi bila diperlukan; Penyimpanan sementara limbah padat di Rumah Sakit harus ditempatkan di TPS Limbah padat sebelum dilakukan pengangkutan, pengolahan dan atau penimbunan limbah padat; Penyimpanan limbah padat menggunakan wadah/tempat/kontainer limbah padat dengan desain dan bahan sesuai kelompok atau karakteristik limbah padat; Penggunaan warna pada setiap kemasan dan/atau wadah Limbah sesuai karakteristik Limbah padat. Warna kemasan dan/atau wadah limbah padat tersebut adalah: Merah, untuk limbah radioaktif; Kuning, untuk limbah infeksius dan limbah patologis; Ungu, untuk limbah sitotoksik dan Cokelat, untuk limbah bahan kimia kedaluwarsa, tumpahan, atau sisa kemasan, dan limbah 
farmasi.

Pemberian simbol dan label limbah padat pada setiap kemasan dan wadah limbah sesuai karakteristik limbah. Simbol pada kemasan dan wadah Limbah tersebut adalah: Radioaktif, untuk Limbah radioaktif; Infeksius, untuk Limbah infeksius; Sitotoksik, untuk Limbah sitotoksik

dan

Toksik/flammable/campuran/sesuai dengan bahayanya untuk limbah bahan kimia.

Berdasarkan hasil penelitian, dengan informan penelitian di ketahui kegiatan Tempat Penampungan Sementara (TPS) di Puskesmas Perawatan Betungan Kota Bengkulu. Sudah sesuai dengan Peraturan Menteri Kesehatan Nomor 7 Tahun 2019 tentang Kesehatan Lingkungan Rumah Sakit, hal tersebut terlihat dari bangunan yang tertutup dari sinar matahari, memiliki tempat penampungan limbah sudah memiliki sekat pembatas dari tempat penampungan dan tempat penampungan tidak langsung bersentuhan dengan lantai, dan dilengkapi deangan fasilitas keselamatan. Penyimpanan limbah padat medis Puskesmas Perawatan Betungan Kota Bengkulu, diletakkan di dalam TPS Rumah Sakit yang berada di halaman belakang Rumah Sakit yang berdekatan dengan insenerator.

Hal tersebut juga di buktikan oleh hasil observasi yang peneliti lakukan, dimana berdasarkan temuan lapangan menunjukan bahwa bangunan sudah terbuat dari bangunan yang tertutup dari sinar matahari, memiliki tempat penampungan limbah sudah memiliki sekat pembatas dari tempat penampungan dan tempat penampungan tidak langsung bersentuhan dengan lantai, dan dilengkapi deangan fasilitas keselamatan. Penyimpanan limbah medis padat.

Penelitian ini sejalan dengan penelitian Wulandari (2012). Adanya Tempat Penampungan Sementara (TPS) berfungsi untuk mencegah terjadinya penularan baik melalui udara, kontak langsung, maupun melalui binatang (Wulandari, 2012).

Berdasarkan hasil penelitian, Tempat Penampungan Sementara (TPS) untuk menyimpan limbah medis di Puskesmas Perawatan Betungan Kota Bengkulu sudah terpisah dengan limbah non medis. Akan tetapi Tempat Penampungan Sementara (TPS) non medis masih terdapat sampah medis di dalam Tempat Penampungan Sementara (TPS) non medis.

Menurut (Peraturan Menteri Kesehatan Nomor 7 Tahun 2019 tentang Kesehatan Lingkungan Rumah Sakit) ruang penyimpanan limbah medis harus bebas banjir dan harus terhindar dari gangguan serangga dan jauh dari jangkauan manusia. Untuk itu adanya penutup untuk membatasi akses sehingga hanya orang yang berkepentingan saja yang dapat memasuki area TPS (Kemenkes, 2019).

Bangunan untuk penyimpanan limbah medis di Rumah Sakit terbuat dari semen yang kedap air, memiliki atap, penerangan dan saluran air untuk TPS medis Rumah Sakit sesuai dengan kriteria PP Nomor 101 Tahun 2014 tentang limbah medis. Persyaratan bangunan TPS yang sesuai dengan PP Nomor 101 Tahun 2014 yaitu bangunan memiliki desain dan kontruksi yang mampu melindungi limbah medis dari hujan dan sinar matahari, memiliki penerangan dan ventilasi, memiliki saluran drainase dan bak penampung. Pada pengemasan limbah medis Rumah Sakit menggunakan kemasan yang terbuat dari plastik, untuk limbah medis kantong warna kuning dan limbah non medis kantong warna hitam (PP Nomor 101 Tahun, 2014).

Pengolahan Lanjutan Limbah Medis Padat B3 Menurut Permenkes RI nomor 7 Tahun 2019 Pengolahan limbah medis, harus memenuhi ketentuan teknis sebagai berikut : Pengolahan limbah medis padat keluar Rumah Sakit dilaksanakan apabila tahap pengolahan limbah padat diserahkan kepada pihak pengolah atau penimbun limbah dengan pengangkutan menggunakan jasa pengangkutan limbah padat (transporter limbah padat); Cara Pengolahan limbah medis padat harus dilengkapi dengan SPO dan dapat dilakukan pemutakhiran secara berkala dan berkesinambungan; Pengolahan limbah medis padat harus dilengkapi dengan perjanjian kerjasama secara three parted yang ditandatangani oleh pimpinan dari pihak Rumah Sakit, pihak pengangkut limbah dan pengolah atau penimbun limbah padat; Rumah 
sakit harus memastikan Pihak pengangkut dan pengolah atau penimbun limbah memiliki perizinan yang lengkap sesuai dengan ketentuan peraturan perundang-undangan. Izin yang dimiliki oleh pengolah maupun pengangkut harus sesuai dengan jenis limbah yang dapat diolah/diangkut.

Berdasarkan hasil penelitian, diketahui kegiatan Pengolahan limbah medis padat di Puskesmas Perawatan Betungan Kota Bengkulu, sudah sesuai dengan Peraturan Menteri Kesehatan Nomor 7 Tahun 2019 tentang Kesehatan Lingkungan Rumah Sakit, Puskesmas Perawatan Betungan Kota Bengkulu tidak memiliki izin pengelolaan limbah dengan menggunkan insenerator, maka dari itu Puskesmas Perawatan Betungan, bekerja sama dengan pihak ketiga yaitu PT. Nikosa dalam proses pengelolaan limbah medis, pengangkutan limbah Puskesmas ini menggunakan mobil khusus, biasanya ada pemberitahuan dari Puskesmas biasanya limbah di TPS medis segara harus di angkut pihak puskesmas unit kesling menghubungi pihak ketiganya kemudian dengan menggunakan mobil khusus yang tertutup datang menuju TPS medis dilakukan pengangkutan sebelum pengangkutan itu dilakukan penimbangan volume limbah yang akan di angkut, kemudian sesuai dengan kontrak juga keluar dari gerbang Puskesmas Perawatan Betungan tidak lagi tanggung jawab dari Puskesmas Perawatan Betungan jadi sepenuhnya tanggung jawab pihak ketiga. Mobil masuk sampai depan TPS petugas yang mengakut dan menimbang juga dari pihak ketiga dan limbah medis diangkut oleh pihak ketiga.

Hal tersebut juga di buktikan oleh hasil observasi yang peneliti lakukan, dimana berdasarkan temuan lapangan menunjukan bahwa Puskesmas Perawatan Betungan sudah bekerja sama dengan pihak ketiga yaitu PT. Artama Sentosa untuk pengelolaan limbah medis dikarenakan Puskesmas Perawatan Betungan Kota Bengkulu tidak memiliki izin pengelolaan limbah menggunakan insenerator karena pipa pembakaran kurang tingggi mengakibatkan polusi di sekitar Puskesmas Perawatan Betungan
Kota Bengkulu yang tidak standar dengan spesifikasi insenerator Puskesmas Perawatan Betungan Kota Bengkulu belum standar sesuai Kementerian Lingkungan Hidup Republik Indonesia maka Puskesmas Perawatan Betungan Kota Bengkulu bekerja sama dengan pihak ketiga/ pihak pengelolaan limbah yaitu PT. Artama Sentosa.

Proses pengangkutan di lakukan oleh pihak ketiga Pada proses pengangkutan limbah padat medis dimasukan ke dalam trolly berwarna kuning dan untuk limbah padat domestik dimasukkan ke dalam trolly pengangkutan limbah medis mudah dibersihkan, dikeringkan dan dibersihkan (Adisasamito, 2011).

Puskesmas memiliki insenerator di dekat lokasi TPS medis, akan tetapi insenerator tidak memiliki izin pengelolaan tidak dapat dipergunakan. Maka dari itu, Puskesmas menggunakan jasa pihak ketiga untuk pengolahan limbah medis, kemudian dilakukan pengangkutan saat sampah medis sudah bayak di TPS medis. Sebelum diangkut oleh pihak ketiga dilakukan penimbangan dan pencatatan terlebih dahulu limbah medis (Yunizar, 2014)

Hal ini sudah sesuai dengan peraturan yang ada yaitu apabila rumah sakit/puskesmas tidak memiliki insenerator, maka untuk proses pengolahan limbah medis padat dilakukan dengan kerja sama Puskesmas lain atau diserahkan kepada pihak ketiga. Akan tetapi pada proses pengambilan limbah medis padat Puskesmas oleh pihak ketiga, dilakukan pada saat limbah medis sudah penuh di TPS medis (Wulandari, 2012).

\section{KESIMPULAN}

Evaluasi pengelolaan limbah medis padat di Puskesmas Perawatan Betungan Kota Bengkulu, yaitu : Identifikasi limbah medis padat B3 sudah sesuai dengan Permenkes No. 7 Taun 2019, karena sudah mengelompokan jenis- jenis limbah sesuai karateristiknya yang terdiri dari limbah infeksius, patologi, limbah benda tajam, limbah farmasi, limbah sitotoksik, limbah kimiawi. Pemilahan limbah medis padat B3 belum sesuai dengan Permenkes No. 7 Taun 2019, karena 
masih terdapat limbah medis terletak di dalam tempat sampah non medis seperti bekas sarung tangan, kasa pemalut bekasa darah, kapas bekas cairan, bekas botol biyus dan bungkus obat yang masih ada terlihat di dalam tempat sampah non medis. Pewadahan dan pengangkutan limbah medis padat B3, Pengangkutan limbah belum sesuai dengan Permenkes No. 7 Taun 2019, karena petugas pengangkut limabah masih tidak menggunkan APD lengkap seperti sarung tangan hanya sebelah saja tidak menggunkan semua sarung tangan dan masker tidak di paki dengan benar hanya di letakan di dagu tidak menutupi mulut dan hidung saat melakukan pengangkutan limbah. Tempat Penampungan Sementara (TPS) medis padat B3 sudah sesuai dengan Permenkes No. 7 Taun 2019, karena memiliki bangunan yang tertutup dari sinar matahari, sekat- sekat pemisah limbah dan memiliki tempat penampungan limbah sesuai jenis dan karakteristik, tidak bersentuhan langsung dengan laintai, memiliki alat keselamatan. Pengolahan lanjutan Limbah Medis Padat B3 di Puskesmas Perawatan Betungan sudah sesuai dengan Permenkes No. 7 Taun 2019. Rumah Sakit bekerja sama dengan pihak ketiga/ pihak pengelolaan limbah yaitu PT. Artama Sentosa, karena tidak memiliki izin penggunaan insenerator karena pipa pembakaran kurang tingggi mengakibatkan polusi di sekitar Puskesmas Perawatan Betungan Kota Bengkulu yang tidak standar dengan spesifikasi insenerator Puskesmas Perawatan Betungan Kota Bengkulu belum standar sesuai Kementerian Lingkungan Hidup Repoblik Indonesia.

\section{DAFTAR PUSTAKA}

Astuti. 2014. Kegiatan Pengelolaaan limbah di Rumah Sakit Umum Propinsi Nusa Tenggara Barat. Dalam Jurnal Comunity Health Vol. 2 No. 1 Bali: Universitas Udayana.

Adisasmito,W.2011. Faktor Risiko Diare Padabayi dan Balita di Indonesia:Systematic Review Penelitian Akademik Bidang Kesehatan
Masyarakat.Makala Kesehatan vol.11, no.1,juni 1-1.

Ramon, A., Husin, H., \& Handayani, U. (2020). B3 Medical Waste Management Analysis In Rafflesia Hospital, Bengkulu City. Avicenna: Jurnal IImiah, 15 (3), 211-217. https://doi.org/10.36085/avicenna.v15i 3.1349

Asmadi. 2013. Pengelolaan Limbah Medis Rumah Sakit. Yogyakarta: Goysen Publishing.

Hapsari, Riza. 2010. Analisis Pengelolaan Sampah dengan Pendekatan Sistem di RSUD Moewardi Surakarta. Thesis. Semarang. UNDIP

Hamidi. 2010. Metode penelitian kualitatif. Malang: UMM Press.

Komariah, Aan. 2017. Metodologi penelitian kualitatif. Bandung: Alfabeta.

Lime, $\mathrm{Rr}$ Domy, 2013. Evaluasi Sistem Pengelolaan Sampah Rumah Sakit Umum Daerah Blambangan Banyuwangi. Vol. 7, No. 1/Juli 2013. Surabaya

Notoatmodjo, Soekidjo. 2015. Metodologi Penelitian Kesehatan. Jakarta: Rineka Cipta..

Peraturan Menteri Kesehatan Nomor 7 Tahun 2019 tentang Kesehatan Lingkungan Rumah Sakit.

Purwanti. 2018. Pengelolaan limbah padat bahan berbahaya \& beracun (B3) Rumah Sakit di RSUD Dr.Soetomo Surabaya, Jurnal Kesling Vol. 10 No. 3. Surabaya: Universitas Erlangga.

Purwanti, Dyah. 2013. Analisis Sistem Pengelolaan Limbah medis Padat Pukesmas Kabupaten Pati. Semarang: Univesitas Negeri Semarang.

Puskesmas Perawatan betungan, 2019. Profil Puskesmas Perawatan Betungan.

Peraturan Pemerintah Republik Indonesia Nomor 101 Tahun 2014 Tentang Pengelolaan Limbah Bahan Berbahaya dan Beracun.

Rachmawati, 2018. Analisis Manajemen Pengelolaan Limbah Padat Medis B3 di Rumah Sakit Universitas Sebelas Maret Surakarta. Dalam Jurnal Volume ke 9 
Surakarta : Fakultas Teknik Universitas Wahid Hasyim.

Ratu, Wiraswaty Kusumah, 2014. Studi Pengelolaan Sampah RS dan Prospek Pengembangannya di Kota Makassar Skripsi. Universitas Hasanudin. Makassar.

Sugiyono,2012. Metode penelitian kualitatif dan F\&D. Bandung, Alfabeta.

Wulandari, Puri. 2012. Skripsi Upaya Minimalisasi dan Pengelolaan Limbah Medis di Rumah Sakit Haji Jakarta Tahun 2011. Universitas Indonesia; Jakarta
Yulian. 2016. Evaluasi Sistem Pengelolaan Limbah Paat (medis dan Non Medis) RS DR. Soedirman Kebumen. Skripsi: Universitas Negeri Semarang.

Yunizar, Ahmad. 2014. Sistem Pengelolaan Limbah Padat Pada RS Dr. H. Moch. Ansari Saleh Banjarmasin. Jurnal Vol. 1 No. 1 2014. Banjarmasin

Zuhriyani, 2019. Analisis Sistem Pengelolaan Limbah Medis Padat Berkelanjutan di Rumah Sakit Umum Raden Mataher Jambi. Dalam jumlah pembangunann berkelanjutan Vol. 1 No. 1 Jambi: Universitas Jambi 